\title{
Order allocation in a multi-supplier environment: Review of the literature since 2007
}

\author{
Joan Ignasi Molinè, Anna Maria Coves \\ Universitat Politècnica de Catalunya (Spain) \\ jnasi@,hotmail.com,.anna.maria.coves@upc.edu
}

Received: September 2012

Accepted: March 2013

\section{Abstract:}

Purpose Optimal order allocation on the part of the buyer in a multi-supplier environment has become a major concern in supply chains. There are numerous articles that analyze and present models for optimizing order allocation from a given panel of suppliers. The purpose of this paper is to provide an analysis on this topic which considers: (i) aims, (ii) results, (iii) model complexity, and (iv) resolution procedures.

Design/mathoddogy/approadr. The paper reviews twenty-eight articles, twenty-one of them published since 2007 in journals indexed by Journal Citation Reports (in ISI Web of Knowledge) on this topic.

Findings: This review reveals four main aspects mentioned as determinant in generating mathematical models. The analysis of these four points does not allow for a single, overarching model. Rather, all analyzed solutions reflect and respond to a specific company environment.

Originality/value A global analysis on several recent papers, describing main aspects wich determines optimal order allocation in multi-supplier environment.

Keywards: order allocation, suppliers, mathematical models 


\section{Introduction}

Optimal order allocation by a purchaser in a multi-supplier environment has become extremely important in current supply chains. In general, order purchasing management has three principal aims: reduce acquisition costs, insure delivery punctuality and ensure quality requirements on the part of the suppliers. These aims must be aligned with and inscribed within a company's strategic framework, as well as incorporating and developing purchasing capabilities (Gonzalez-Benito, 2007). Purchasing management aims are especially important in industrial goods production settings involving on-going product order allocation, where proper management contributes to decrease company costs.

The influence of acquired products and services (purchases) on manufacturing companies' cost structure is highly variable, and all cases, significant. In automobile manufacturers, procurement constitutes 68-79\% (ICEX, 2009; Pallarés, 1997) of manufacturing costs, while in the chemicals industry, depending on the sector, procurement represents between $42 \%$ and $71 \%$ of production costs (FEIQUE, 2008). Given this cost structure configuration, defining actions that reduce purchasing costs is strategically significant as such actions will have a direct impact on increasing profits.

For these reasons, purchasing management has a direct effect on company results, such as one of its principal aims will be minimization of procurement costs (acquired products/services). To achieve this, different strategies may be developed, one of the most important being optimal order allocation from the panel of suppliers. Optimal order allocation will be conditioned by (among other factors) existing suppliers panel previously chosen through assessment and homologation by the purchasing company.

The described scenario motivates this article, which reviews twenty-one articles published in journals indexed by Journal Citation Reports (in ISI Web of Knowledge), between 2007 and the present. The articles analysed here look at optimal order allocation from a panel of suppliers in which there is a single purchaser and $\mathrm{N}$ suppliers. This state of the art does not include a previous assessment and homologation of supplier.

The following section includes an analysis of those aspects that this review has revealed as determinant in generating mathematical models. Finally, in section 3, on the basis of this review of the state of the art, conclusions are drawn.

\section{Analysis of State of the Art (since 2007)}

In this present state of the art, we analyze four main aspects; (a) Aims, (b) results (variables), (c) model complexity and (d) type of resolution procedure utilized. 


\subsection{Aims}

The most common objective function is cost minimization ( 9 cases, $42.9 \%$ ). There are also models that consider profit maximization (4 cases, $19 \%$ ) and other eight cases $(38.1 \%)$ where a multi-objective model has been developed.

Multi-objective models oscillate between two and four objective functions. In general, one of these functions is purchasing cost minimization. The other functions vary, with the most noteworthy being maximization of purchasing value and minimization of: defects, and late deliveries.

Despite the fact this state of the art only covers order allocation, it worth mentioning that six (28.6\%) of the articles integrate the assessment and supplier selection phases with order allocation.

\subsection{Results}

In general, the purchaser has a need (demand) for $Q$ units, and assigns to the suppliers a quantity qi (for each supplier $\mathrm{i}$ ), such that $\Sigma$ qi $=\mathrm{Q}$.

The common decision of all the articles (21 cases, 100\%) are the quantities purchased from each supplier that may be accompanied by other variables: time between orders, procurement point, stock levels, quantity of final product to be produced, etc. It must be stressed that at the same time that order allocation for panel suppliers is being undertaken, some articles consider that supplier selection is also taking place, as there may be suppliers that will fill zero orders.

\subsection{Model Complexity}

Mathematical models are made up of one or several objective functions and a set of restrictions. The greater the number of parameters incorporated in the objective functions, and the more aspects of the purchaser's environment reflected in the restrictions, the more complete and complicated (complex). Complexity is mainly determined by two axes (Table 1):

- Depth: this axis shows the number of stages in the supply chain presented in the model. The more stages included in the supply chain, the more complete and complex the model.

- Characteristics: Range of costs and company environment parameters introduced. These depend on the particular characteristics of the company, the sector it belongs to, and the decisions made by the purchasing department (single-period vs. Multi-period, randomness...). The model will be more or less complex depending on the degree to which these factors are incorporated into it. 
Table 1 synthesizes the two above mentioned axes, such that the upper row designates the stages of the supply chain, and for each of the stages in the corresponding column, the characteristics that can be incorporated are described. Characteristics are subdivided into two categories: Costs and Company environment, in which all the costs and factors specific to each stage (in the supply chain) are detailed, as well as those factors that affect all stages in the supply chain.

The depth axis is designed to reflect the articles analysed in the study. For this reason the stages in the supply chain are not enumerated. Stages such as reception logistics, storage forwarding, and shipping logistics are not specified, and whose company environment factors and/or costs have been included in columns: Purchases and Demand. In the same way, with rigor, the concept "Quality" should be general for all stages and include a wide range of factors in each stage, which one can observe how quality has been incorporated as a previous stage to that of Production. This is because in the analysed articles, quality is linked to technical usefulness (or not) of the purchased products. Aspects that are a quality parameter, such as delivery time, are included in other stages, such as Purchases. Finally, it is important to stress that the Production stage is complex, involving many company environment factors and costs. The analysed articles that include the production stage greatly simplify it. For this reason, the Production stage only reflects factors and costs described in those analysed articles.

\begin{tabular}{|c|c|c|c|c|c|c|}
\hline & \multicolumn{5}{|c|}{ Depth } \\
\hline & & Purchasing & $\begin{array}{l}\text { Warehouse } \\
\text { reception }\end{array}$ & Quality & Production & Demand \\
\hline \multirow{3}{*}{ 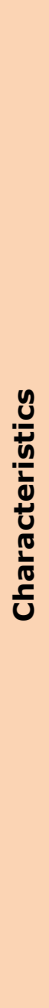 } & $\begin{array}{l}\text { 岇 } \\
\text { ठ̊ }\end{array}$ & $\begin{array}{l}\text { - Procurement costs. } \\
\text { - Available discounts. } \\
\text { - Ordering costs. } \\
\text { - Transportation costs. } \\
\text { - Management costs. }\end{array}$ & $\begin{array}{l}\text { - Raw } \\
\text { material } \\
\text { holding } \\
\text { costs. } \\
\text { Reception } \\
\text { costs. }\end{array}$ & $\begin{array}{l}\text { - Selection } \\
\text { costs } 100 \% \text {. }\end{array}$ & $\begin{array}{l}\text { - Raw } \\
\text { material } \\
\text { transformati } \\
\text { on costs. }\end{array}$ & $\begin{array}{l}\text { - Finished product } \\
\text { holding costs. } \\
\text { - Shortage costs. } \\
\text { - Sales price of pieces. } \\
\text { - Sales price of } \\
\text { defective pieces }\end{array}$ \\
\hline & \multirow[t]{2}{*}{ 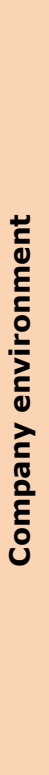 } & $\begin{array}{l}\text { - N suppliers. } \\
\text { - Single product vs multiple } \\
\text { products. } \\
\text { - Supplier production capacity. } \\
\text { - Prioritization of suppliers } \\
\text { (mínimum order, weight } \\
\text { assignement, maximum or } \\
\text { minimum number of } \\
\text { suppliers. } \\
\text { - Budget available. } \\
\text { - Supplier delivery time. } \\
\text { - Reorder point. } \\
\text { - Supplier uncertainty } \\
\text { (quantity and delivery time). } \\
\text { - Presence of 3PL. }\end{array}$ & $\begin{array}{l}\text { - Storage } \\
\text { space for } \\
\text { each article. } \\
\text { - Maximum } \\
\text { stock } \\
\text { capacity. } \\
\text { - Raw Material } \\
\text { stock. }\end{array}$ & $\begin{array}{l}\text { - Percentage } \\
\text { of correct } \\
\text { pieces (or } \\
\text { defective). } \\
\text { - Minimal } \\
\text { acceptable } \\
\text { quality. } \\
\text { - Selection } \\
\text { rate. }\end{array}$ & $\begin{array}{l}\text { - Production } \\
\text { rate. } \\
\text { - One finished } \\
\text { product vs } \\
\text { multiple } \\
\text { finished } \\
\text { products. }\end{array}$ & $\begin{array}{l}\text { - Constant and } \\
\text { random demand. } \\
\text { - Number of } \\
\text { shipments per cycle. } \\
\text { - Finished product } \\
\text { stock. }\end{array}$ \\
\hline & & \multicolumn{5}{|c|}{$\begin{array}{l}\text { - Single vs. multiple periods. } \\
\text { - Single buyer. } \\
\text { - Push/pull system. } \\
\text { - Type of chosen modelling. } \\
\text { - Cost variation per period vs fixed costs per period. } \\
\text { - Other strategies: possibility of outsourcing, risk inclusion, warehouse location decisions,... }\end{array}$} \\
\hline
\end{tabular}

Table 1. Description of axes (depth and characteristics) determining model complexity 
The content of each of the columns (stages) is not exhaustive, since depending on the interest of the buyer, more factors could be added. The table shows those factors most frequently cited in the articles analysed. Additionally, those costs and company environment factors included within one of the supply chain stages are not necessarily present in all models including that stage. Every model includes the characteristics corresponding to the sector/company under analysis or to the academic model being developed. The analysed models will be classified according to the two indicated axes. To assure the objectiveness of this classification, the calculating key indicators for each of the two axes is defined;

- Depth indicator, supply chain stages, is a integer number determined by the number of stages (defined in Table 1) included in the model.

- Characteristics indicator is measured using the following formula:

$$
\text { Characteristics Indicator }=\text { Costs } * 0.5+\text { Environment } * 0.5
$$

Therefore characteristics indicator is determined $50 \%$ by costs, and $50 \%$ by the company environment described in the model. In order to measure both values Table 2 is defined. Where for each stage in the supply chain both costs and company environment factors have been detailed, in case to be included in the model, a value of 1 is assigned. If not, the value will be 0 . Regarding factors that are transversal, at all stages, multiperiodicity is assigned a value of 1 . If the model is single-period, the value assigned is 0.3 , and the same criteria is used regarding single or multiple product order allocation or single or multi objective functions. By so doing, the greater complexity of models including multi variants is shown.

\begin{tabular}{|l|l|l|}
\hline \multirow{4}{*}{ Suppy Chain } & Costs & Company environment \\
\hline \multirow{3}{*}{ Purchases } & RM acquisition costs & Supplier capacity \\
\cline { 2 - 3 } & Ordering costs & Priorization of suppliers \\
\cline { 2 - 3 } & Transportation costs & Discounts \\
\cline { 2 - 3 } & & Delivery deadline \\
\hline \multirow{2}{*}{ Quality } & RM storage costs & Storage capacity \\
\cline { 2 - 3 } & & RM stock \\
\hline \multirow{2}{*}{ Production } & $100 \%$ selection costs & Percentage of correct pieces \\
\hline Storage Forwarding & & Selection rate \\
\hline \multirow{2}{*}{ Final Client } & Storage costs FP & Production rate \\
\hline \multirow{3}{*}{} & Shortage costs & FP Stock \\
\cline { 2 - 3 } & & Final customer demand \\
\hline & & Sales price \\
\cline { 2 - 3 } & & Single vs multiple periods \\
\cline { 2 - 3 } & & Single or multiple products \\
\hline
\end{tabular}

Table 2. Format for calculating characteristics indicator included in model 
Using the corresponding calculation, each of the articles has been plotted along the fore mentioned axes (Figure 1). Results allow for an approach to study the dispersion of the scope covered by the analyzed models. Table 3 describes correspondence between codes and articles.

Visual analysis of Figure 1, allow appreciating a cloud of points, within which one observes; differentiated points and a total of five clusters of points. The five clusters of points are formed by articles: [12][17], [7][26], [18][23][2], [1][24], and [21][16][4]. Each cluster includes articles containing the same number of stages and similar or equal degree of characteristics indicator. With the support of information included in the articles, one observes that in general these articles partially coincide with respect to the stages included, but differ in the rest of the stages. Despite the fact that the characteristics indicator rate is similar, in the articles in each cluster, costs and company environment factors are different. Consequently the models reflect different situations.

For this reason, a visual analysis of the differentiated points, and a more detailed analysis of the clusters allow us to affirm that all twenty-one articles (100\%) analyse different cases, whether for the depth or company environment included. Likewise, one observes that 9 (42.85\%) models include two stages and 5 (23.8\%) include 3 stages. In 14 models (66.7\%), characteristics indicator is greater than $50 \%$.

\begin{tabular}{|c|l|}
\hline Code & Articles/Authors \\
\hline 1 & Abginehchi and Farahani (2010) \\
\hline 2 & Bidhandi, Yusuff, Ahmad and Bakar (2009) \\
\hline 3 & Burke, Carrillo and Vakharia (2008) \\
\hline 4 & Burke, Carrillo and Vakharia (2009) \\
\hline 7 & Cervera and Coves (2009) \\
\hline 10 & Hajji, Gharbi, Kenne and Pellerin (2011) \\
\hline 11 & Haleh and Hamidi (2011) \\
\hline 12 & Hassini (2008) \\
\hline 14 & Kirytopoulos, Leopoulos, Mavrotas and Voulgaridou (2010) \\
\hline 15 & Kokangul and Susuz (2009) \\
\hline 16 & Lin (2010) \\
\hline 17 & Lin (2009) \\
\hline 18 & Mafakheri, Breton and Ghoniem (2011) \\
\hline 19 & Mendoza and Ventura (2010) \\
\hline 21 & Rezaei and Davoodi (2008) \\
\hline 22 & Sawik (2010) \\
\hline 23 & Tsai and Wang (2010) \\
\hline 24 & Ustun and Demirtas (2008) \\
\hline 26 & Woo and Saghiri (2011) \\
\hline 27 & Wu, Sukoco, Li and Chen (2009) \\
\hline 28 & Zhang and Ma (2009) \\
\hline
\end{tabular}

Table 3. Correspondence between codes and articles 


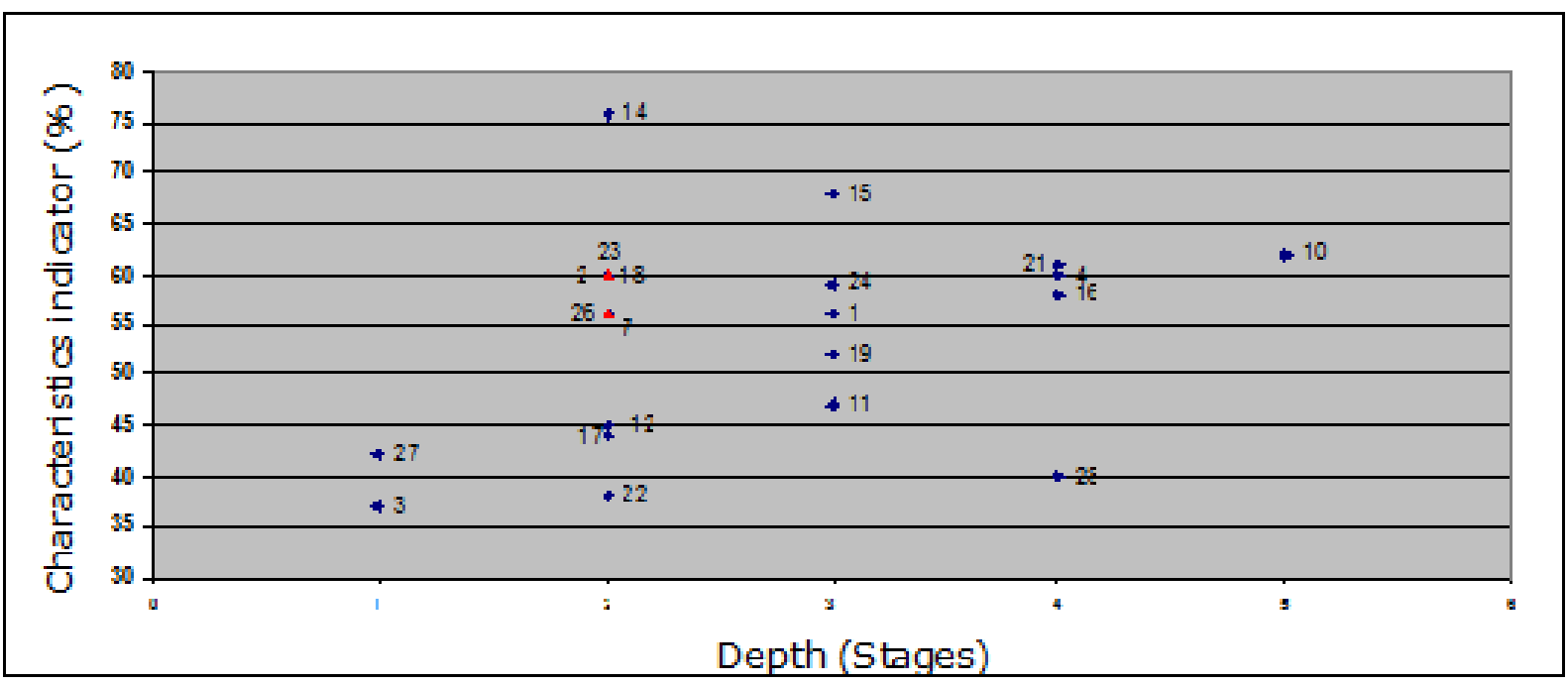

Figure 1. Graph measuring depth and characteristics indicator of analyzed articles

\subsection{Resolution Procedures}

Model classification is carried out using two main procedures: exact procedures and heuristics procedures (heuristics). Within the firsts; 4 articles (19\%) use dynamic programming, 2 articles (9.5\%) linear programming, 4 (19\%) mixed integer linear programming, and 1 (4.8\%) nonlinear integer programming. The heuristics are subdivided into those based on exact procedures and those that are not. In heuristics one observes that; 3 articles (14.3\%) are based on mixed integer linear programming; 1 (4.8\%) nonlinear programming; $3(14.3 \%)$ non lineal integer programming; 2 (9.5\%) dynamic programming; and 1 article (4.8\%) based on heuristic procedures.

\section{Conclusions}

Various conclusions may be drawn from this overview of the state of the art. The most significant conclusion is the absence of an overall order allocation model in a multi-supplier environment. Partial solutions exist depending on the depth of the supply chain, as well as the costs and company environment factors considered, including particular aspects of the company and sector in question. Thus there are a wide range of approaches, and each model addresses specific characteristics, and tries to reflect the reality of the company under study. In other cases, articles try to model specific academic hypotheses. There are also a variety of resolution procedures utilized.

While not within the scope of this state of the art, our study found a number of articles that consider techniques for creating a supplier panel.

On the basis of the state of the art analysis, new research lines have been initiated aimed at designing a comprehensive model that incorporates the entire management of the supply chain, as well as parameters that go beyond the specific area of purchasing. 


\section{Acknowledgements}

The authors gratefully acknowledge the partial support of grant DPI2010-15614 (Ministerio de Economia y Competitividad, Spain).

\section{References}

Abginehchi, S., \& Farahani, R.Z. (2010). Modeling and analysis for determining optimal suppliers under stochastic lead times. Applied Mathematical Modeling, 34(5), 1311-1328. http://dx.doi.org/10.1016/j.apm.2009.08.021

Bidhandi, H.M., Yusuff, R.M., Ahmad, M.M.H.M., \& Bakar, M.R.A. (2009). Development of a new approach for deterministic supply chain network design. European Journal of Operational Research, 198(1), 121-128. http://dx.doi.org/10.1016/j.ejor.2008.07.034

Burke, G.J., Carrillo, J., \& Vakharia, A.J. (2008). Heuristics for sourcing from multiple suppliers with alternative quantity discounts. European Journal of operational Research, 186(1), 317-329. http://dx.doi.org/10.1016/j.ejor.2007.01.019

Burke, G.J., Carrillo, J., \& Vakharia, A.J. (2009). Sourcing decisions with stochastic supplier reliability and stochastic demand. Production and Operations Management, 18(4), 475-484. http://dx.doi.org/10.1111/j.1937-5956.2009.01022.x

Cervera, D., \& Coves, A.M. (2009). Analyze and designing of allocation models in multi-supplier environments, based on MILP. Proceedings 3rd International Conference on Industrial Engineering and Industrial Management, 347-355.

FEIQUE, Federación empresarial de la industria química española (2008). Observatorio industrial del sector químico Evolución de la indústria química española (2003-2007). Retrieved Setember 8, 2012. http://bit.ly/10JScQQ

Gonzalez-Benito, J. (2007). A theory of purchasing's contribution to business performance. Journal of Operations Management, 25(4), 901-917. http://dx.doi.org/10.1016/j.jom.2007.02.001

Hajji, A., Gharbi, A., Kenne, J.P., \& Pellerin, R. (2011). Production control and replenishment strategy with multiple suppliers. European Journal of Operational Research, 208(1), 67-74. http://dx.doi.org/10.1016/j.ejor.2010.08.010

Haleh, H., \& Hamidi. A. (2011). A fuzzy MCDM model for allocating orders to suppliers in a supply chain under uncertainty over a multi-period time horizon. Expert Systems with Applications, 38(8), 9076-9083. http://dx.doi.org/10.1016/j.eswa.2010.11.064

Hassini, E. (2008). Order lot sizing with multiple capacitated suppliers offering leadtimedependent capacity reservation and unit price discounts. Production Planning\&Control, 19(2), 142-149. http://dx.doi.org/10.1080/09537280801896177 
ICEX, Instituto Español de Comercio Exterior. (2009). El mercado de automoción y de sus componentes en India. Retrieved May 12, 2011. http://bit.ly/1850Xbu

Kirytopoulos, K., Leopoulos, V., Mavrotas, G., \& Voulgaridou, D. (2010). Multiple sourcing strategies and order allocation: an ANP-Augmecon meta-model. Supply Chain Managementan International Journal, 15(4), 263-276. http://dx.doi.org/10.1108/13598541011054643

Kokangul, A., \& Susuz, Z. (2009). Integrated analytical hierarch process and mathematical programming to supplier selection problem with quantity discount. Applied mathematical modelling, 33 (3), 1417-1429. http://dx.doi.org/10.1016/j.apm.2008.01.021

Lin, T.Y. (2010). An economic order quantity with imperfect quality and quantity discounts. Applied Mathematical Modeling, 34(10), 3158-3165. http://dx.doi.org/10.1016/j.apm.2010.02.004

Lin, R.H. (2009). An integrated FANP-MOLP for supplier evaluation and order allocation. Applied Mathematical Modelling, 33(6), 2730-2736. http://dx.doi.org/10.1016/j.apm.2008.08.021

Mafakheri, F., Breton, M., \& Ghoniem, A. (2011). Supplier selection-order allocation: A twostage multiple criteria dynamic programming approach. International Journal of Production economics, 132(1), 52-57. http://dx.doi.org/10.1016/j.ijpe.2011.03.005

Mendoza, A., \& Ventura, J.A. (2010). A serial inventory system with supplier selection and order quantity allocation. European Journal of Operational Research, 207(3), 1304-1315. http://dx.doi.org/10.1016/j.ejor.2010.06.034

Pallarés, M. (1997). El sistema de producción flexible, el just in time y la transformación espacial. La empresa del automóvil en España. Boletin de la AGE, 24, 53-71.

Rezaei, J., \& Davoodi, M. (2008). A deterministic multi-item inventory model with supplier selection and imperfect quality. Applied mathematical modeling, 32(10), 2106-2116. http://dx.doi.org/10.1016/j.apm.2007.07.009

Sawik, T. (2010). Single vs. multiple objective supplier selection in a make to order environment. Omega: The international journal of management science, 38(3-4), 203-212. http://dx.doi.org/10.1016/j.omega.2009.09.003

Tsai, W.C., \& Wang, C.H. (2010). Decision making of sourcing and order allocation with price discounts. Journal of Manufacturing Systems, 29(1), 47-54. http://dx.doi.org/10.1016/j.jmsy.2010.08.002

Ustun, O., \& Demirtas, E. A. (2008). An integrated multi-objective decision-making process for multi-period lot-sizing with supplier selection. Omega: The international journal of management science, 36(4), 509-521. http://dx.doi.org/10.1016/j.omega.2006.12.004 
Woo, H.S., \& Saghiri, S. (2011). Order assignment considering buyer, third-party logistics provider, and suppliers. International Journal of Production Economics, 130(2), 144-152. http://dx.doi.org/10.1016/j.ijpe.2010.10.019

Wu, W.Y., Sukoco, B.M., Li, C.Y., \& Chen, S.H. (2009). An integrated multi-objective decisionmaking process for supplier selection with bundling problem. Expert Systems with Applications, 36(2), 2327-2337. http://dx.doi.org/10.1016/j.eswa.2007.12.022

Zhang, G., \& Ma, L. (2009). Optimal acquisition policy with quantity discounts and uncertain demands. International Journal of Production Research, 47(9), 2409-2425. http://dx.doi.org/10.1080/00207540701678944

Journal of Industrial Engineering and Management, 2013 (www.jiem.org)

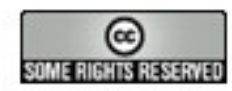

Article's contents are provided on a Attribution-Non Commercial 3.0 Creative commons license. Readers are allowed to copy, distribute and communicate article's contents, provided the author's and Journal of Industrial Engineering and Management's names are included. It must not be used for commercial purposes. To see the complete license contents, please visit http://creativecommons.org/licenses/by-nc/3.0/. 